\title{
KAMUSAL ALAN MODELLERI: GOĞULCU PERSPEKTIFTEN BIR DEĞERLENDIRME
}

\author{
Dr. Ahmet Karadağ \\ Inönü Üniversitesi \\ iktisadi ve İari Bilimler Fakültesi
}

\section{Özet}

Arcndt'in Antik Yunan Polis devletindeki kamuyu idealize ettiği model, kamusal alana katılım ve gündemin belirlenmesi açısından özgürlük, eşitlik ie çoğulculuk ilkeleri çerçevesinde yeniden kavramsallaştırılmaya gereksinme göstermektedir. Liberal kamu modeli kamusal alana katılım konusunda özgürlük ve eşitlik ilkelerine uygun olup, nihai çoğulculuğa da açıktır. Ancak, liberal kamu modelinde kamusal gündem sınırıdır. Habermasian model ise, yurttaşların kanusal müzakereye katılımının eşitlik ve özgürlük ilkeleri çerçevesinde dïzenlenmesini kabul eder. Kamusal gündeme de herhangi bir sınırlama getirilmesine ilke olarak karşı olan bu model, nihai çoğulculuk bakımından günümüz demokratik toplumları iç̣in elverişli değildir. Bu nedenle, kapsayıcı yeni bir kamusal alan modeline ihtiyạ̧ vardır. Bu çalışmada mevcut kamu alanı modellerinin çoğulculuk açısından eksiklikleri tartışılarak. ihtiyał̣ duy̧ulan yeni kamu alanı modeline ilişkin öngörülerde hulunulmuştur.

Anahtar Kelimeler: Kamusal alan, kamusall gündem, kamusal akıl, f̧oğılculuk, siyasil adalet.

\section{Models of Public Sphere: An Assessment Through Pluralist Perspective}

\section{Abstract}

The model that idealised public sphere in ancient Greck Police state by Arende needs to be reconceptualised in terns of participation to public sphere, determining, political agenda and making a framework of the principles of freedom, equality and pluralism. I.ibcral public model is open to and sujtable with the principles of frecdom and equality concerning the participation in public sphere. But, in liberal public model, public agenda is limited. Whereas Habenuasian model aceepts citizen's participation in public discussions in the framework of the principles of equality and freedom. This model, which is principally against any limitation of public agenda, is not useful in today's democratic societies from pluralist point of view. For this reason. there is a necd for a comprehensive and new public sphere model. In this study, present public sphere models arc discussed and criticised from the point that pluralism has not been taken into account. Some predictions are suggested on new public sphere molels which are really needed.

Key Words: Public sphere, puhlic agende, public reason, pluralism, social justice. 


\section{Kamusal Alan Modelleri: Çoğulcu Perspektiften Bir Değerlendirme}

\section{GiRiş}

Kamusal alan kavramı farklı biçimlerde ve farklı boyutları içerecek şekilde tanımlanabilir. Rappa (2002:7) kamusal alanı beş farklı boyutta tanımlamaktadır. Buna göre kamusal alan (1) insanların iletişiminin ve etkileşiminin fiziksel bir alanı, (2) insan eylemlerinin oluşturduğu fiziksel olmayan metaforik bir alan, (3) iki taraf arasındaki bilgi alış verişinin farklı biçimlerinin bulunduğu bir mekan, (4) ilişkilerin farklı eklemlenme biçimlerinin ve entelektiucl veya entelektüel olmayan tartışmaların meydana geldiği bir alan, (5) devletlerin ve devlet dışı aktörlerin planlanmış veya planlanmamıs politikalarının ortaya çıktığı bir alan olabilir. Bir başka tanıma göre kamusal alan, devletin oluşumu, ev ve iş dışındaki konularda katılım, ortak ilgi konuları üzerine kamusal tartışmalar, bunlara ck olarak kamusal yapılar ve mekanların oluşturulmasıdır (ABERCROMBIE vd., 1994: 340) Hangi boyutta ve nasıl tanımlanırsa tanımlansın uyumsuzlukların ve çıkar çatışmalarının karakterize ettiği kamusal alan, demokrasi açısından büyük bir önem taşır.

Demokrasi ise sürckli değişen, gelişen ve derinleşen bir kavramdır. Antik Yunan'da "halkın iktidarı" olarak anlaşılan demokrasi, günümüzde Mouffe'un deyimiyle "öznelcrin çoğulculuğu"na dayalı bir sisteme dönüşmektedir. Buna bağlı olarak demokratik mücadele ckonomik ve siyasal sinırların dışına taşmakta, bu mücadelede farklı toplumsal kesimlerin farklılıklarına ilişkin hak talcpleri önem kazanmaktadır. Yani, demokraside yeni bir yön değişimi yaşanmaktadır. Demokrasideki bu değişime nasıl bir kamusal alan cşlik etmclidir? Kamusal alandaki kimlik ve farklılık taleplerinden doğan çatışmalar nasıl çözüme kavuşturulmalıdır?

Dördüncü kuşak haklarm konusunu oluşturan kimlik ve farkhlığa ilişkin hakların salt bir iktidar sorunu olarak görülüp bu zaviyeden çözüme kavuşturulması, farkh toplumsal kesimlerden bir kısmmm kendi yaşam alanlarını diğerlerinin aleyhine genişletmesiyle çözümlenmesi demek olacaktır. 
Bu durum, son tahlilde Sartori'nin (1996:32) belirttiği gibi "halkın halk üzerindcki iktidarı" anlamına gelecektir. Böyle durumlarda yönetim bir çoğunluğa dayansa da hiçbir zaman kimlik ve farkhılığa dayalı hak taleplerine çare olamayacaktır. Çünkü, bu tür yönetimler belli bir çoğunluğa dayanmak bakımından biçimsel olarak meşru olmalarına karşın, hak taleplerine istenilen yanıtları verememekten dolayı özsel açıdan meşruluk sorunu bulunan yönetimlerdir. Kimlik ve farklılığa dayalı yeni hak taleplerine uygun yönetimler oluşturabilmek, bizi çoğulculuk kavramına götürmektedir.

Siyasal kuramda iki tür çoğulculuktan söz edilebilir. Bunlar; çokkültürcülük ve liberal çoğulculuktur. Çokkültürcülük, siyasal karar alma süreçlerine farklı toplum kcsimlcrinin örgütlü olarak katılabilmeleri anlamındaki geleneksel çoğulculuğu aşan bir içeriğe sahiptir. Bu anlamda çokkültürcülük, "farklı yaşam pratikleri içinde oluşan kültürel farklılıkların siyasal düzcyde tanımması ve eşit ölçüde saygıdeğer kabul cdilmesi" esasına dayanır (KÖKER, 1996: 12). Bu yönüyle çokkültürcüluik, toplumdaki etnik, ırksal ya da kültürel farkh kesimlerin çoğulluğuna vurgu yapar (YÜRÜŞEN, 2001: 119). Çokkültürcülüğ̈̈n temel kavramı tanımadır. Tanıma kavramının önemi toplumsal hiyerarşilerin sona ermesiyle ortaya çıkmıştır. Toplumsal hiyerarşilere dayanan modern öncesi toplumlarda insanlar arasinda şeref bakımından üstünlük farklılığı bulunmaktaydı. Bir kimsenin belli bir şerefe sahip olabilmesi, ancak diğer kimsclerin ayn şerefe sahip olmamasıyla mümkündü. Geleneksel toplumlarda kişilerin toplumsal statüleri, sahip oldukları şcrefe göre değişiyordu. Modern toplumda ise, artık kişiler arası bir şeref farklılığ ve bu farklı şerefe dayalı toplumsal statüler, yerini insanlık haysiyetine bırakmıştır. İnsanlık haysiyeti kavramı cvrenselci ve eşitlikçi bir anlama sahiptir (TAYLOR, 1996: 44). Yani, bu haysiyet tüm insanların insan olmak açısından sahip olduklanı eşit bir değerdir. Taylor'a göre tanıma olmaksızın çoğulculuk mümkün değildir. Çünkü, tanımama veya yanlış tanıma bireyin kişiliğinin yanlıs tanınması, çarpıtılması veya onun aşağı bir konuma itilmesine neden olabileceği gibi, bircyin böyle bir varoluş biçimine sokularak baskı altında tutulmasına da yol açabilir. Tanıma olmaksızın bireyin bireyselleşmiş, kendine özgü ve kendi içinde keşfettıği bir kimliğe dayalı kendi özel varoluş biçimine uygun davranma demek olan sahicilik de yaşama geçirilemez (TAYLOR, 1996: 44).

Liberal çoğulculuk etnik, ırksal ya da kültürel bir çoğulculuk olmayıp, bir değer çoğulculuğudur. Değcr çoğulculuğu evrensellik, çoğulluk, çatışma ve kıyaslanamazlık gibi dört unsuru içerir (CROWDER, 2002: 459). Bu açıdan liberal çoğulculuk, bir toplumdaki ctnik, ırksal ve kültürcl çoğulluğun "ön ve temel kabulüyle birlikte değerlerin, tutumları, modellerin, projelerin çoğulluğunu" esas alır (YÜRÜŞEN, 2001: 119). 
Liberal çoğulculuk modern birey anlayışı üzerinde temellenmiştir. Farklı düşünce ve inançların, bunların temsil ettikleri değerlerin, bireyin dışında aşkın bir anlamı yoktur. Bütün bu düşünce, inanç ve değerler bireysel özgürlüğc hizmet etmeleri bakımından önemlidir (YÜRÜŞEN, 2001: 122). Bu nedenle liberal çoğulculukta önem kazanan kavram hoşgörüdür. Hoşgörü saycsindedir ki, farklı yaşam tarzlarına sahip kesimler, farklılıklarına rağmen barış içinde bir arada yaşarlar. Bir toplumda farklı yaşam tarzlarının bulunması bireyler açısından alternatiflerin varlığını gösterir. Her alternatif; bir tercih ögesi içerdiğinden, tercihlerini "etik ve rasyonel bakımdan temcllendirebilen" insan demek olan bireylerin varlığını gerektirir. Bireylerin ise, özerk birer varlık olarak kendi potansiycllcrini ortaya koyabilmesi, karşısında bulduğu farkh alternatifler dizisi içinden scçim yapabilmesi için özgür olması zorunludur (BERLIN, 1969: 168). Liberal düşünce açısından çoğulculuk, bircylerin özerk olabilmesinin temel koşullarından biridir (YÜRÜŞEN, 2001: 123).

Her iki çoğulculuk biçiminde özgürlük ve eşitlik farklı anlamlara sahiptir. Liberal çoğulculukta özgürlük ve eşitlik siyasal alan açısından soyut bir kültürel artalandan hareketle oluşturulmuştur. Çokkültürcülüktc ise, tam tersine, farklılık talepleriyle eşitlik ve özgürlük kavramları arasında bir ilişki vardır. Özgürlük ve eşitlik kavramlarının bu farklı içerikleri kamusal alan kavramsallaştırmalarına da farklı biçimde yansımaktadır. Kanusal alan modellerini çoğulcu perspektiften tartışmalı hale getiren de budur zaten.

Bu çalışmada kamusal alan modelleri olarak Arendtian, Habermasian ve liberal model özgürlük, eşitlik ve çoğulculuk açısından değcrlendirilerek, gereksinme duyulan kapsamlı bir kamusal alan kuramının nasıl olması gerektiğine ilişkin öngörülcrde bulunulmuştur. Çalışmada Benhabib (1996: 238) tarafından yapılan üçlü ayrım esas alınmış ve konu sadece normatif açıdan incelenmiştir. Ayrıca, çalışmada kamusal alanın tartışmaya yönclik kısmı konu edinilmiş, kamusal yapı ve mekanlara ilişkin bölümü çalışma kapsamının dışında tutulmuştur.

\section{ARENDT'TE KAMUSAL ALAN: REKABETCGI VE BIRLESTIMSEL MODEL}

Cumhuriyet ve sivil yaşam açısından erdemi önceleyen geleneğin kamu alam anlayışı olan rekabetçi (agonistik) ve birleşimsel görusşün önémli temsilcisi Arendt'tir.

Insanlık Durumu adlı yapıtında Arendt, Antik Yunan'daki rekabetçi siyasal alanı idealize eder. Antik Yunan'daki "polis" yönctiminde rekabetçi siyasal alana katılabilmek, sadece günlük yaşamını kazanmak için çalışma zorunluluğundan kurtulabilmiş crkek yurttaşların hakkıydı. Kadınlar, köleler, 
emekçiler ve yabancılar siyasal alana katılamazken, erkeklerin ise, ekonomik gereksinmelerden bağımsız olmanın yanında anne ve baba tarafından iki kuşak öncesinden özgür olmaları gerckliydi.

Antik Yunan dönemi, kamusal ile özel arasındaki ayrımın açık biçimde ortaya çıktığı dönemdi. Siyasal alan kamuyu temsil ederken, hane özcl alanı temsil ediyordu. Hanenin karakteristik özelliği, insanların burada istek ve gereksinmelerinin güdümünde bir arada yaşıyor olmalarıdır. Bireyin yaşamını sürdürmesi ve türün bekası başkalarıyla birlikte yaşamayı gerektirdiğinden, bu birliktelik yaşamsal bir zorlama olarak ortaya çıkınıştır. Buna karşın, polis bir özgürlük alanıydı. Çünkü, özgürlük, insanların birlikte hareket etmeleri, diğer bir deyişle ortak bir dünya yaratma girişimleri sonucunda oluşan yeni sonuçlar ve yeni ilişkiler gerektirdiğinden, ancak, yurttaşların birbirleriyle karşılaşıp yeni ilişkiler kurdukları. açık kamusal alanlarda ortaya çıkabilirdi. Fakat, özgürlügün gerçckleşme mekanı olan kamusal alana katılabilmck için hanedeki yaşamsal zorunluluklardan özerk yurttaşlar olmak gerckliydi. Polistcki özgürlügün koşulu, hanedeki yaşamsal zorunluluklara egemen olmaktan geçiyordu (ARENDT, 1994: 47-50).

Polis, yalnız eşitleri tanıyor olmak bakımından haneden ayrılıyordu. Hane tam anlamıyla eşitsizliğin merkezi iken, polis eşitlerin ve özgürlüğün alanıydı. Hanede özgürlük yoktu, çünkü hane reisi "sadece haneden ayrılıp herkesin eşit olduğu siyaset alanına girebilecek güce sahip" olmak bakımından özgür kabul ediliyordu (ARENDT, 1994: 52).

Antik dönemde kamusal ile özel alanın belirginleştirilmesinde mülkivet önemli bir yer tutmuştur. Bir kimsenin herhangi bir şekilde dünyanın belli bir kısmında bir yer sahibi olması ve bu sahiplik nedeniyle bir siyasal oluşuma aitliği, yani birliktc kamusal alanı oluşturan ailelerden birinin reisi olması demek olan mülkiyet sayesinde insanlar özel alandan kurtularak kamusal alanda görünebiliyorlardı. Elde ettiği mülkiyet sayesinde insanlar günlük tüketimlerini sağlamakla uğraşmamakta, böylece kamusal etkinliklerde bulunmak açısından özgür olmaktalardı (ARENDT, 1994: 90-93).

Hanenin yaşamsal işlevlerinden olan ekonomik işlevlerin kamusal alana çıkışlarıyla ev yönetimiyle ilgili önceleri özel alana ait olan bütün konular kolektif bir nitelik kazanmıştır (ARENDT, 1994: 53).

Antiklerin hanenin dar alanını aşarak siyasetin alanına yüksclebilmek için geçmek zorunda oldukları mesafenin ortadan kalkmasına neden olan bu gelişme tamamen modernleşmenin bir sonucudur (ARENDT, 1994: 54).

Hanenin ekonomik devamlılığı ile ilgili evcil olarak nitelendirilcbilecek işlevlerin kamusal alana çıkışı, bir taraftan özel ile kamusal olan arasında eskiden var olan sınırı bulanıklaştırırken, diğer yandan bu iki kavramın 
anlamını ve birey ile yurttaşın yaşamı açısından ifade ettiği gerçekliği de büsbütün değiştirdi (ARENDT, 1994: 59).

Toplumsalın doğuşu, hane ile ev yönetimine ilişkin etkinliklerin "kamu alanına girişinden itibaren, bu yeni alanın en belirgin özelliklerinden biri, daha yakın bir zaman içinde kurulan mahremiyet alanının yanı sıra, eskinin siyasal ve özel alanlarını aşındırma ve yutma yönünde karşı konulmaz bir cğilimin serpilip gelişmesi oldu" (ARENDT, 1994: 68).

Özel alan olarak hane, türün sürekliliği ve bireysel beka ile yaşamsal zorunluluklara çareler aranan ve bulunan çarelerin sağlama alındığı bir uzamdı. Mahremin keşfinden önce gizlilik, insanların sadecc insan cinsinden bir havvan turünün mensubu olmasını da ifade ediyordu. Zaten, Antik dönemde salt özel alanda kalışın aşağılanıyor olmasının temel nedeni de buydu. Toplumsalın yükselişi ile bcraber özel alan cskiyle karşılaştırılamayacak derecede itibar kazandı. Ama, özcl alanın antik doğası hemen hị̧ değişmedi (ARENDT, 1994: 69). Agamben'in kavramlaştırmasıyla özel alan kazandığı tüm değere karșın, yine de ureme ve yaşamda kalma alanı, yani zoe'yi ifade ediyordu. Bios'un alanını ise, eskiden olduğu gibi kamusal alan oluşturuyordu (KESKIN, 1998 : 96).

Kamusal yaşamda aynı nesnenin farklı kişiler tarafindan algılanması söz. konusudur. Bu da konum farklılıkları ve buradan kaynaklanan perspektif çç̧itliliğini ortaya koyar (ARENDT, 1994: 84). Kamu alanının bu çoğul anlamı özel kavramının mahrum kılıcılık niteliğini de bclirlemektedir. Tamamen özel bir yaşam başkalarınca görülmek ve duyulmak gibi gerçekliklerden ve yaşamda kalıcı bir şeyler başarma olanağından insanlanı mahrum eder. Böyle bir yaşam içindeki bireyin ötekilerine göre durumu reel bir anlaın ifade etmez (ARENDT, 1994: 86). Çükü. salt özcl yaşama bağlı bir insan diğer insanlar yönünden yok hükmündedir; bu insanın diğerleri için herhangi bir etkisi olmadığı gibi, diğer insanlar da salt özel yaşam içindeki insan açısından önemsiz ve etkisizdir. Modern koşullarda böyle bir yaşam kitlesel yalnızlıktır.

Modernleşmeylc birlikte toplumlar kurumsal farklılaşmalar yaşamışlardır. Bu farklılaşmalar sonucu siyasal alan, pazar alanı ve ailc olmak üzere toplumda üçlü bir ayrışma yaşanmıştır. Modern öncesi dönemde ev işleri içinde yer alan ckonomik işler modernleşmeyle birlikte kamusallaşmışlardır. Böylece kamusal alana yeni konular ve yeni özneler müdahil olmuștur. Arendt (1994: 59-73) bu gelişmcleri "toplumsalın yükselişi" olarak adlandırmaktadır. Toplumsalın yükselişi, polisteki siyasal katılımcı insan anlamında kamusal insanın çöküşü demck olmuştur.

Arendt'de kanusal alan iki görüngüye sahiptir (ARENDT, 1994: 74-85). İlk görüngü kamusal alanın bir zuhur alamı olmasıdır. İkinci görüngüye görc 
ise, kamu herkes için ortak olan insan ürünü şeylerle ilgilidir. Ortak bir dünya, her bir kimsenin konum farklılıkları ve buradan kaynaklanan perspektif çeşitliliğine karşın, aynı nesneyle ilgilenmesini gcrcktirir. Tersi bir durumda "ortak dünyanın kcndini insani çoğulluğa sunduğu sayısız veçhe tahribata uğrar". Artık söz konusu olan tckil deneyimlerin öznelliğidir; tek bir yanıyla görülmeye başlanan ve tek bir perspektiften sunulmasına izin verilen, bu nedenle de sona eren ortak bir dünya.

Arendt'in kamu alanı anlayışı rekabetçi ve birleşimscl olmak üzere iki farklı biçimde oluşabilir. Rekabetçi biçimiyle kamu alanı, kişilerin kendi farklılıklarını, ortaya koyarak başkalarından üstünlüklerini göstercbileceği alanı ifade eder. Kamusal alanda yapılan her etkinliğin, gizlilik alanında karşılığı olmayan bir erdeme ulaşması olasıdır. Tanımı gereği crdem, başkalarının varlığını gerektirir ve bu varlığın da kişinin akranlarınca oluşturulan resmi bir kamu içinde oluşması gerekir (ARENDT, 1994: 72).

Modern öncesi dönemde insanlar, yaşama kendilerinden bir şeyler katabilmek ve daha kalıcı bir scylere sahip olabilmek için kamusal alana girmişlerdir (ARENDT, 1994: 81). Romalılar açısından res publica, Yunanlılar açısından polis bireysel yaşamın faniliğine karşı birer güvence alanı idiler (ARENDT, 1994: 82). Yani, kamusal alan bireyin ölümsïzlük aradığı alandı.

Kamusal alanın bu rekabetçi yönü yanında bir de birleștirici yönü bulunmaktadır. Birleşimscl yönüyle kamusal alan "insanların uỵum içinde birlikte hareket ettikleri" her yerde ve her zaman ortaya çıan, özgürlüğün kendini gösterebildiği uzamdır (BENHABIB, 1996: 241). Bu anlanda kamusal alan topoğrafik ya da kurumsal bir mekan olmak zorunda değildir.

Kamusal alanla ilgili bu ikili ayrım Antik Yunan politik deneyimine karşılık gelmektedir. Polisin rekabetçi bir niteliğe sahip olması kamu alanında eylemde bulunan kimsenin, yaptığı eylemle kendisini başkalarına açıklamak istemesidir. Kamu alanına çıkan insanlar için bu alan bir zuhur, bir görüntü alanıdır. Bu etkinlik karşılıklı olduğundan kamusal alan, kendi farklılıklarını göstermek ve ötekinin farklılığını görmek isteyenlerin eylemsel buluşma alanıdır. Yani, kamusal alan, bir taraftan sahip olunan farklılıklar dolayısıyla insanları rekabete ve çekişmeye iterken, diğer taraftan farklı insanların karşılıklı olarak farklılıklarını gösterme amacına hizmet etmektedir.

Arendt'in kamusal alanı bu şekilde kavramsallaştırması onun politika konusundaki görüşleriyle de bağlantılıdır. Bu bağlamda Arendt, politikayı salt bir iktidar alanı olarak görmez. Arendt'e göre (1994:19) politika, farklılık, çoğulluk, iletişim, diyalog ve özgürlük gibi insan yaşamının daha yüksek potansiyellerinin ortaya çıkmasına olanak sağlar. "Çoğulluk, insani cylemin koşuludur, çünkü hepimiz aynıyız; yani hiç kimsenin şımdiye dek yaşayan. 
yaşayacak başka herhangi biriyle asla aynı olmayacağı tarzda insanız". Politika ise özgürlük alanı olan poliste gerçckleşir.

Arendt'c görc özgürlük politikanın varlık nedeni, eylemin isc deneyim alanıdır. Insanlar ancak eylemde bulundukça özgür olabilirler. Zira, özgür olmakla cylemde bulunmak aynı şey demektir. Eylemde bulunabilmek için de bireyler arası özgür ilişkiler gerekir (BERKTAY, 2002: 99).

Arendt, özgürlügü insani varoluşun politik boyutu açısından olmazsa olmaz bir değer olarak kabul eder. Dolayısıyla, özgürlüğü felsefi bir konu olmak yerinc politik bir konu olarak değerlendirir. Çünkü, özgürlük felsefi bir kavram olarak ele alınırsa egemenlik kavramıyla özdeşleşmekte, bu da ya özgürlügün inkarına yol açmakta ya da başkalarının özgürlüğünü kendi özgürlüğümüzün alternatif maliyeti konumuna getirmektedir. Bunun yerinc Arendt, özgürlüğü politika yapmak anlamında polisin özgürlüğü olarak elc alır (BERKTAY, 2002: 100). Polis bir yaşam biçimidir. Bu yaşam biçiminde insanlar eylem ve söylem yoluyla bir bekaya ulaşma çabası içindedirler. Polisin önemi yaşamsal zorunluluklardan özcrk olarak insani cylemlerin gerçckleşmesi için bir arena olmasındandır. Bu bakımdan Arendt'te polisin ozgürlüğün ve farklılığın ortaya çıkmasımı, dolayısıyla düşünen ve eyleyen varlığın bütünleşmesini sağlayan tarihsel ve toplumsal bir mekan olduğu söylenebilir.

Arendt, Batı metafizik geleneğine karşı alternatif bir kamusal alan kavramsallaştırması amacıyla yola çımıs, ancak böyle bir kamusal alan için Antik Yunan Polisi'ni ideal bir mekan olarak kabul etmiştir. Her ne kadar bu kabulüyle Arendt'in amacı polisin temcl özelliklerini oluşturan kimi kavram ve uygulamaları anlamsal açıdan çağdaş yorumlara kavuşturmak olarak kabul edilse de, toplumsalın yükselişiyle birlikte bireylerin özgürlük ve mutluluğu politik alan yerine toplumsal alanda kalmakta buldukları yadsmamaz bir gerçektir. Zaten, Arendt de (1994.65) bir siyasal toplumda nüfusun artmasıyla kamusal alanın siyasal alandan çok toplumsal alan tarafından belirleneceğini kabul ctmektedir. Bu bakımdan Arendt' in kamusal alan kavramsallaştırmasını, Antik Yunan Polisi'nin özelliklerine sahip bir mekanda gerçckleşebilecek kamusal alan modellerinin özel bir türü olarak değerlendirmek olasıdır.

Antik Yunan Polisi için geçerli olan rekabetçi kamu alanı giriş koşulları ile tartışma gündemi açısından etik ve siyasal homojenlik kriterleriyle önceden belirlenmiştir. Belli bir mülkiyeti bulunan ve ev yönetimine ait işlerle kendisi ilgilenmek zorunda olmayan özerk erkekler bu kamu alanında görüncbilmektedirler. Modern kamu alanı ise giriş, aktörler ve tartışma konuları bakımından nesnel kriterlerle önceden belirlenebilme özclliğinden yoksundur. 


\section{LIBERAL KAMU ALANI}

Liberal kamu alanı açısından erken dönem liberal anlayışı ile günümüzdeki liberal yaklaşım arasında önemli farklılıklar bulunmaktadır. Bu nedenle önce klasik liberal düşünürlerden Locke ve Mill'in kamusal alana ilişkin görüşlerine yer verilecek daha sonra çağdaş liberal düşünürlerin konuyla ilgili görüşleri cle alınacaktır.

\subsection{John Locke ve J. Stuart Mill'de Kamusal Alan}

Locke'un yönetim kuramı siyasal toplumun doğası kavramına dayanır. Bu kavram kamu ve özcl arasında güçlü bir ayrımı varsayar. Siyasal toplum aileden (özcl alandan) farklı, hatta ona karşıt olarak tanımlanmıştır. Öyle ki, kamusal ile özel arasında bir ayrım kabul edilmediğinde Locke açısından politik alan da yok demektir (STEINBERGER, 1999).

Locke, konuyla ilgili görüşlerini doğa durumuna dayalı olarak açılar Doğa durumu, insanların herhangi bir kimseden izin almadan ve başka birinin iradesine bağımlı olmadan doğa yasasına göre yaşadıkları, eylemlerini düzenlemek ve mallarını istedikleri gibi kullanabilmek açısından özgür oldukları bir durumu ifade eder. Doğa durumu hem bir özgürlük hem de eşitlik dunımudur. Çünkü, doğa durumunda yaşamakta olan herkes açısından her türlü erk ve yargı hakkı karşılıklıdır. Hiç kimse bir diğerinin aleyhine olarak fazladan bir yetkiyc ya da hakka sahip değildir (LOCKE, 1986: 229).

Doğa durumunda karşılıklı etkileşimler ve bireysel etkinlikler doğa yasasına göre işler. Doğa yasası ise, bizzat aklın kendisidir. Doğa yasası olan akıl sayesinde kişiler kendilerini korumaktan daha "soylu" bir neden olmadıkça diğer kişilerin özgürlüğüne zarar vermezler. Çünkü, Locke'a göre (1986:230-1) tüm insanlar Tanrı'nın malıdırlar ve aralarında ontolojik bir hiycrarşiden söz edilemez. Doğa yasasına aykırı hareket edenler, herkes karşılıklı olarak ceza verme yetkisine sahip olduğundan, bu yetki çerçevesinden cezalandırılır. Ancak insanların benlik sevgisi ve huy kötülüğü nedeniyle ortaya çıkacak sorunların çözümü karmaşaya yol açabilir. Çünkü, doğal düzende belirli, yerleşik ve bilinen bir yasa, bilinen ve nesnel bir yargı̨̧ ve etkin bir yürütme erki bulummamaktadır. Bu nedenle insanlar siyasal topluma geçerler.

Siyasal alan özel alandan farklıdır. Siyasal topluma geçişle birlikte her bir kimse doğal durumdaki yetkilerinden kendisini konuma yetkisini kısmen, cezalandırma yetkisini ise tamamen bırakıp hiçbir kesimle ilgisi olmayan nötr kurallar aracılığıyla hakemlik yapmak üzerc oluşturulmuş toplumun otoritesine boyun eğcr. Lockc’a göre (1986:229) siyasal toplum mülkiyetin, yaşam ve özgürlüğün korunmasıyla sınırlandırılmıştır. Bu bağlamda siyasal güç “mülkiyetti düzenlemek ve korumak için ölüm cezası ve dolayısıyla haydi haydi 
bundan daha az şiddetli cezalar verebilen yasalar koymak, bu yasaları uygulamak ve devleti yabancıların işleyeceği zararlardan esirgemek için topluluğun gücünü kullanmak, bütün bunları da yalnızca kamunun iyiliği uğruna yapmak hakkı"dır

Locke'in kurguladığı doğa durumunda eşit hak ve sorumluluktan kaynaklanan bir ortaklık durumu söz konusudur. Wolin (1999:64) bu ortaklığın mutlak bir homojenliğe ve yapaylığa yol açtığın belirtmektedir. Özellikle sözleşme sırasında mülkiyet, sınıf, din, dil, cinsiyet, ırk ve etnik farklılıklar görmezlikten gelinmektedir. Efendi-köle, anne-baba ile çocuklar, karı-koca arasındaki ayrımlar siyasal niteliğe sahip olmadıkları gerekçesiyle ozel alana indirgenmektedir. Buna sebep ise, homojen ortak bir paydanın kaynaklık edeceği bir önerme olmadan sözleşmeye işlerlik kazandıracak mekanizmanın kurulamayacak olmasıdır. Egemen bir siyasal birlik oluşturma açısından, diğer bir deyişle sözleşme nedeniyle bir norm olarak homojenliğe vuirgu yapan Locke, çıkar çatışmaları ve görüş ayrılıklarının olabileceği gerçeğini de göz ard 1 etmcz

John Stuart Mill toplumsal alanla siyasal alamı birbirinden ayırır. Mill'e göre toplumsal alan farkh bireyselliklerin karşlıklı etkileşimde bulundukları bir alanı ifade eder. Toplum halınde yaşayan insanlar bunun gereği olarak toplumdaki diğer insanlara karşı belli sorumluluklarla yükümludürler. Bu sorumluluk her birey için iki tür yükümlülük getirir. Birincisi, yasal hükümler ya da zımni anlaşmalarla birer hak olarak kabul edilen menfaatlere zarar vermemektir. Íkincisi ise, toplumun ve üyelerinin olası zararlardan korunması için yapılan çalışma ve fedakarlıklardan her bireyin, payına düşene katlanmasıdır. Mill, bu iki gerekçe dışında bircylerm yaptıkları harcketlerin sadece kendileri için sonuç doğurması durumlarına müdahale edilmemesi gerektiğini savunur. Bu gibi durumlarda bireyler gerek yasal gerekse sosval açıdan özgür olmalıdırlar. Ancak, Mill bu durumun tam bir kayıtsızlık durumu olarak anlaşılmaması gerektiğini belirtir.

Bireylerin, sonuçları bakımından sadece kendilerini etkileyen eylemleri gerek yasal-siyasal otorite gerekse diğcr bireyler tarafindan istenilmeyen veya yapılması hoşa gitmeyen cylemler olabilir. Böyle durumlarda öteki kimselere düşen sadecc eylemi yapana telkinden ibarettir. Yapılan bu tclkin bireyin özgürlüğünc müdahale olmayıp diğer bircylerin bireyselliklerini kullanma özgürlüklerinin bir sonucudur. Çünkü, Mill'e göre toplumsal alanda farkh kesimler arası diyaloğun temel önkoşulu karşılıklı olarak bireyselliklere saygidır (MILL, 1988: 144-6).

Siyasal alanın kurulmasmda ise Mill iki temel ilkeden hareket eder. Birinci ilke teleolojik bir ilke olarak kabul edilebilir. Buna göre "en iyi hükümet biçimi hor türlü uygarlık durumunda uygulanabilir ya da seçilebilir bir 
biçim değil, fakat uygulanabilir ve seçilebilir olduğu koşullarda, o gün ve daha ileride, en büyük nicelikte yararlı sonuçları doğuran bir hükümet biçimidir". İkinci ilke isc, "her yurttaşın ... arada sırada, yerel ya da genel bir kamu görevini kişisel olarak ycrine getirmck üzere, hükümette gerçek bir görevi yüklenmeğe" çağrılmasını gerektirmektedir (MILL, 1986: 70). Yurttaşların yönetime katılması ancak temsili biçimde olabilecektir. Mill'e göre temsili yönetim sadece çoğunluğun haklarını ve çıkarlarını korumaz; aynı zamanda azınlığın da korunmasını sağlar. Bireysel özgürlüklerin çoğunluğun tahakkümünden korunması için sonuçları bakımından bireyin kendisinden başkasımı ilgilendirmeyen eylemlerine müdahale edilmemesi gerckir. Çoğunluğun tahakkümünü siyasal açıdan önlemenin yolu ise nisbi temsil sisteminden geçmektedir (GÜRiZ, 1963: 151).

Mill'e göre (1986:81) bir ülkede temsili hükümetin kurulup yaşatılabilmesi için halkın temsili hükümeti benimsemeye, korumaya ve gereklerini yerine getirmeye istekli ve yetenekli olması zorunludur. Sabine in (1969:90) belirttiğine göre Mill kendinden önceki liberallerin fark etmediği bir gerçeği yakalamıştır. Buna görc liberal bir sistemin ancak liberal bir toplumla mümkün olabileceğidir. Uygar olmayan toplumlarda temsili hükümetin kurulup işletilebilmesi zordur. Bu nedenle böyle toplumların öncelikle "ilkece müstebit, fakat uygulamada genellikle hayli sınırlı bir merkez iktidarın"ca eğitılmesi gerekir (MILL, 1986: 83-4).

Siyasal alanın sınırı ilc ilgili olarak Mill hizmetlerin hükümet ile özel kesim arasında paylaştırılması açısından hükümet aleyhine üç temel itirazda bulunmaktadır. Önceliklc, yapılacak bir hizmetin özel kesim tarafindan yapılmasının daha iyi olacağıdır. Çünkü özcl kesim tarafından bir işin yapılması demek söz konusu işin liyakat sahibi kimseler tarafindan yapılacak olması demektir. İkinci olarak, herhangi bir hizmetin özel kesim tarafindan yapılması hükümetçe yapılmasından daha iyi olmasa da hizmeti yapan özcl kesimin siyasal ve yönctimsel gelişimine katkıda bulunabilir. Son olarak, yapılması gereken bir hizmetin özcl kesim tarafından yapılması hükümetin gücünün gereksiz yere artırılmasını önlemiş olur (MILL, 1986: 214-16).

\subsection{Friedrich A. Hayek ve John Rawls'da Kamusal Alan}

Çağdaş liberallerden anti-rasyonalist çizg̣ideki Hayek'e göre bir toplumda kitlelerin önemli gereksinmelerinin çoğu, ayrıntıları siyasal iktidar tarafından bilinmeyen süreçlerin sonunda gerçekleşir. Bu nedenle siyasal iktidarın amacı kamusal iyiyi sağlamak için kimi özgül gereksinmeleri gerçekleştirmek olmayıp, farklı kesimlerin kendi gercksinmelerini sağlayabilecekleri koşulları oluşturmaktır (HAYEK, 1995a: 22). 
Tarihsel olarak kamusal ilgi özgül gereksinmelere yönelik olmayıp, farklı toplumsal kesimlerin kendi gereksinmelerini resmi otoriteden bağımsız olarak sağlayabilmelerinin koşullarının oluşturulmasından ibarettir. Hayek'c göre modern özgürlük düşüncesine hizmet etmiş kadim filozoflar kamu yararı ilc adaleti aynı anlamda kullanmışlardır. Harrington'a göre ise kamu yararı ile anlatılmak istenen şcy, her türlü tarafgirlik ve özel çıkardan bağımsız olarak ortak hukuk ve adalettir (HAYEK, 1995a: 22).

Toplumun genel olarak birbirlerini tanımayan üycleri arasında, her birinin kendi amaçlarının görcli önemi üzerinde anlaşma sağlanması olanaksızdır. Zira, hangi özgül çıkarlara diğerleri karşısında üstünlük vcrilirse verilsin bunun sonucu uyum yerine çatışma olacaktır. Bu nedenle farklı özgül amaçlara sahip toplumsal kesimlerin barış içinde bir arada yaşayabilmelerinin sağlanabilmesi için amaçlar yerine araçlar üzerinde bir anlaşmaya varılması gerekir. Üzerinde anlaşmaya varılan araçlar sayesinde öyle bir alan oluşturulur $\mathrm{ki}$, bu alanda farklı kesimler değişik amaçları için eşit şansa sahip olarak hizmet edebilirler (HAYEK, 1995a: 23).

Hayek'in bu görüşlcri onun düzen kavramına ilişkin düsünceleri ile de yakından ilgilidir. Düzen denildiğinde çoğu zaman unsurları bir kimse tarafından yerli yerine konulmuş ve harcketleri de aym kişi tarafindan yönetilen inşa yapılar anlaşıldığını belirten Hayck'e göre, (1994:55-9) her düzen bu kadar basitçe bir araya getirilebilen ve yönctilcbilen yapılardan oluşmaz. Öylesine karmaşık bir ilişkiler ağına ve karmaşık yapılı unsurlara sahip düzenler vardır ki, bunların insan bilgisi sayesinde inşa edilip, geleceğe yönelik olarak belirlenen kimi hedefler doğrultusunda yönctilmesi söz konusu değildir. Toplum da böyle bir düzendir. Çünkü, insanın maddi bilgısi sınırlı, toplum ise bu sımırlı maddi bilgi ile inşa edilip yönetilemeyecek kadar karmaşıtır. Dolayısıyla, toplum kendiliğinden düzenler arasında kabul edilip ona göre yönetilmelidir.

Böylc bir sosyal kuram geliştiren Hayek, sınırlı bir siyasal alan düşüncesine sahiptir. Siyasal düzenin oluşturulmasında kurucu rasyonalizmden kaçınmak gerekir. Çünkü, kurucu rasyonalistlere görc "müdrik" akıl tek tek her eylemi tayin edecek güce sahiptir ve toplumun yeniden inşasında da sadece insan aklı muktedir olmalıdır (HAYEK, 1994: 18, 45; 1997a: 110). Oysa, bir siyasal düzen oluşturulurken kurucu aklın toplumsal her kesimin sahip olduğu farklı iyi anlayışlarını bilme olanağı yoktur. Ayrıca, Hayek siyasal alanda çoğunlığun da sınırlandırılmasını savunur. Hayek'e görc (1997b:200) demokrasi negatif karaktcrli bir "usul" değerdir. Demokrasiyi en iyi yönetim aracı olarak koruyabilmek bu özelliklerinin sürdürülmesine bağlıdır. Bir sistem sımırlı çoğunluğun yönetiminden çoğunluğun tahakkümüne dönüştüğünde, artık 
demokrasiden söz etmek yanıltıcı olur. Sistemi bundan koruyacak olan da kanun hakimiyetidir (HAYEK, 1995b: 88).

Rawls'un kamusal alana ilişkin görüşleri başlangıç durımu, siyasal adalet, kamusal akıl ve örtüşen uzlaşma kavramları çerçevesinde özetlenebilir. Anayasal demokratik bir ortamda yurttaşların eşit ve özgür olma hakkından vazgeçmeksizin birbiriyle çatı̧̧an farklı felsefi, dini ve ahlaki oğretilerlc bölünmüş bir toplumda nasıl yaşanılacağı sorusundan yola çıkan Rawls, siyasal adaleti böyle bir toplumda yaşayabilmenin koşulu olarak öne sürer. Rawls'a göre siyasal adaletin bu işlevini yerine getirebilmesi için kökeninde hiçbir öğreti, kuram, dünya görüşü barındırmaması, herhangi bir öğretiden veva genel iyi anlayışından türetilmemiş olması gerekir. Ancak boyle bir adalet anlayışı ile farklı iỵi anlayışlarının, farklı ve çatışan çıkarların bulunduğu toplumlarda özgür ve eşit olarak yaşanabilir.

Rawls, siyasal adalet ilkelerine ulaşmak için bir başlangıç durumu tasarlar. Başlangıç durumu zaman ve mekan ötesi bir özclliğe sahip, özgür ve eşit kişilerin adil bir anlaşmaya ulaşabilecekleri, havali ve düşünsel bir mekandır. Bu mekanda tasarlanan kişiler sınıf, din, ırk ve cinsiyete dayalı farklı statülerinden habersiz oldukları gibi, kurulması düşünülen toplumdaki çıkarlarından, arzularından, dünya görüşlerinden kısacası kendi iyi anlayışlarından yoksundurlar. İşte, böyle bir durumda bu insanlara nasıl bir toplumda yaşamak istedikleri sorulduğunda, Rawls'a göre bu insanlar siyasal adalctin eşitlik ve fark ilkelerini onaylayarak yanıt vereccklerdir. Başlangıç durumundaki kişiler ahlaki ve akli yetileri nedeniyle özgür ve bu yetileri toplumsal işbirliği amaçlı kullanma kapasiteleri yönünden eşittirler. Kişiler ahlaki ve akli yctileri nedeniylc iki farklı kapasiteye sahiptirler. Bunlardan birincisi makul olma yetisidir. Makul olmak demek siyasal, kamusal adalet görüşünü anlama, uygulama ve buna uygun hareket edebilme demektir. İkincisi ise rasyonel olmaktır. Rasyoncl olmak, kişinin kendi iyisini oluşturabilme kapasitesidir (RAWLS, 1993: 18-9). Makul her kişi kendi hareketlerinin sonuçlarını hesaba katabilen ve diğerlerinin iyiliğini de gözetebilen bir kişidir (RAWLS, 1993: 54). Makul kişi kendisini başkalarına feda etmeveceği gibi bencil de değildir (RAWLS, 1993: 49). Rasyonel kişi ise kendi ivisini seçebilen ve bu iyiyi gerçekleştircbilmek içinveyleme geçebilen kişidir. Makul olmak kişinin siyasal adaletin ilkelcrini anlama ve onaylamasını sağlarken, rasyonel olmak da kapsamlı ya da kısmi öğretilerin, farklı iyilerin ve çıkarların çoğul alamı olan Rawls'un deyimiyle "makul çoğulculuk"u oluşturur. Rawls bu alanı kültürel artalan olarak adlandırır. Kültürel artalanın değerleri siyasal nitelik taşımaz. Siyasal değerler eşit siyasal ve sivil özgürlükler ile firsat eşitliğinden ibarettir. 
Her toplumda bir yanda haklar öte yanda farklı haklılaştımalara sahip iviler bulunur. Rawls'a göre haklar önceliklidir. Haklara öncelik tanınması, farklı toplumsal kesimlerin kendi iyi anlayışlarım hak ve ozgürluklerin önüne geçircrek toplumdaki diğer kesimlerin hak vc özgürlüklerini sınırlandırmalarını engeller (RAWLS, 1993: 174). Burada hakların önceliği ilkesi siyasal adaletin dayandığı ilkelcrden eşitlik ilkesi ile birlikte düşünülmektedir. Buna göre, herkes yeterli bir biçimde düzenlenmiş eşit temel hak ve özgürlükleri eşit olarak kullanma hakkına sahiptir (RAWLS, 1993: 5).

Rawls'un siyasal alan açısından gerekli gördüğ̈̈ bir diğer kavram kamusal akıldır. Rawls, demokratik bir toplumda yasa yapmak ve anayasa değişikliğine gitmek bakımından "kolektif bir bütün olarak birbirleri üzcrinde nihai siyasal ve zorlayıcı güç kullanan eşit yurttaşların" aklı olarak nitelediği kamusal aklın işlevselliğini siyasal alanla sınırlandırır. Kültürel artalana ait sorunlar siyasal değerlerce çözümlenebilecck sorunlardır (RAWLS, 1993: 214). Yani kamusal müzakerenin gündemi kamusal aklın işlevsel olabileceği alanlar açısından sınırlıdır. Ancak, Rawls bu sınırın siyasal adaletin ilkelcri açısından söz konusu olduğunu belirtir. Bir kez siyasal adalet üzerinde uzlaşıldıktan sonra, kamusal doğrulama açısından hangi ilkelerin makul olduğu konusunda farklı görüşler olabilir. Yeter ki, siyasal adalet anlavış̧ı yerine, hiç kimse kendi adalet anlayışını yerleştirme çabasında olmasın (RAWLS, 1993 . 216). Zaten, kapsamlı ya da kısmi farklı iyi anlayışlarının ve öğretilerin bulunduğu bir toplumda anayasal demokratik bir yönetimin kurulabilmesi örtuişen uzlaşmayla mümkündür. Örtüşen uzlaşma ise, toplumdaki farklı her kesimin kendi bakış açısından siyasal adaleti makul olarak gorebilmesidir (RAWLS, 1993: 169). Yani, örtüşen uzlaşma, siyasal adaletin ve onun içerdiği ilkelerin spontane bir sonucudur.

\subsection{Liberal Kamu Alanına lilişkin Genel Bir Değerlendirme}

Çalışma kapsamında ele alınan liberal düşünürler arasında birçok benzerlik ve farklılık bulunmaktadır. Locke, Mill ve Rawls rasyonel gelenekten gelmektedirler. Hayck ise kendisini "müdrik" aklın her eylemi tayin edemeyeceği ve toplumun yeniden inşasında aklın tek muktedir güç olmadığ 1 anlaminda anti-rasyonalist olarak nitelemekte ve Locke'u da rasyonel olmakla eleştirmektedir. Ancak, liberal rasyonellcrin rasyonelliği, Hayck'in kurucu rasyonalistler olarak suçladığı kesimlerin rasyonelliğinden farklıdır. Örneğin, çağdaş liberallerden Rawls'a göre insanlar siyasal adaletin ilkelerini bulabilecek ve anlayabilecek varlıklardır. Benzer biçimde Locke da insanların farklı düzcylerde de olsa doğal yasaları kavrama yetencğine sahip olduklarmı kabul eder. Mill ise, tecrübeyle aklı birleştirmeye çalışır. Yani, liberal 
rasyoncllerin rasyonelliği bireyscl düzeyde olup, bireyin dışında onun eylemlerine geleceğe yönelik yön vermek açısından müdahalede bulunabilen kurucu anlamda rasyonel bir güç söz konusu değildir. Bu durum geliştirilen sosyal ve siyasal kuramlara da yansımıştır.

Locke ve Rawls sözleşmcci geleneğe mensupturlar. Locke'un sözleşme öncesi doğa durumunda toplumu oluşturan bireyler eşit hak ve özgürlüklere sahip olmak açısından homojen bir nitclik gösterirken, Rawls'un başlangıç durumunda toplum, farklılıklarından ve farklı çıkarlarından habersiz olmak açısından homojendir. Bu nedenledir ki, Kukathas, (1990:125) Rawls'u siyasal teorisini ilgisiz ve bilgisiz birey kavramı üzerine kurmuş olduğu gerekçesiyle eleş̧irir.

Locke'da kamusal topluluk sinırhı olup, sadece özgür erkekleri kapsamaktadır. Mill'de ise, kamusal topluluk açısından çelişik bir durum söz konusudur. Başlangıçta kamusal topluluğun genişlemesinden yana görüş beyan eden Mill, daha sonra yönetimin cahil kimselerin eline geçebilcceği tehlikesiyle kamusal toplulığun sınırlandırılmasını ister. Habermas bunu "liberal teoride çatışkılı kamusallık anlayışı" olarak yorumlar. Hayek ve Rawls'da ise, kamusal topluluğa herhangi bir sınırlama getirilmemiştir.

Kamusal gündem açısından klasiklerde görülen sınırlamalar çağdaş liberallerde de bulunmaktadır. Örneğin, Locke'a göre sözleşme sırasında kültürel farklılıklar ile efendi-köle, ana-baba ve çocuklar, karı-koca arasındaki ayrımlar siyasal nitelikli olmadıkları için kamusal gündeme dahil değildirler. Ayıı şckilde Rawls da kültürel artalana ait sorunları siyasal değerlerce çözümlenebilecek sorunlar olarak görü ve bu sorunlar açısından kamusal aklı işlevsel kabul etmez.

Locke, sosyal sözleşme sırasında çoğunluğın kararının ağır basacağını kabul edip, bireylerin rızasını, çoğunluğun veya onların temsilcilcrinin rızası olarak nitelerken, Mill, Hayek ve Rawls çoğunluğun da tahakküme neden olabileceği gerekçcsiyle sınırlandırılmasını savunmaktadırlar.

\section{haBERMASIAN KAMU ALANI: SÖYLEMSEL MODEL}

Habermas üç tuir kamusal alandan söz eder. Bunlar; temsili kamu, edebi kamu ve siyasal kamudur. Kapitalizm öncesi döneme özgü temsili kamu, bir toplumsal alan veya bir kamu alanı olmayıp bir statü belirtisidir. Bu statü, yüce bir kuvvetten kaynaklanan iktidarımı halkın önünde temsil ve teşhir eden feodal hükümdarm statüsüdür (HABERMAS, 2000: 65). 19. yüzyılın başlarına kadar etkisini sürdüren temsili kamuda soyluluk ön plandadir (HABERMAS, 2000: 72,3). Kapitalist döneme geçişle birlikte temsili kamu çözülür. Bu çözülme 
sürecinde temsili kamunun kurumları olan kilisc, krallık ve soyluluk, ortaya çıkan yeni sımıf burjuvazinin çabaları sonucu dönüşüme uğrar.

Kapitalist dönemde öncelikle siyasal kamunun "edebi nitelikli ön biçimi" olan edebi kamu gelişir. Edebi kamu "henüz kendi içinde dönüp duran kamusal akıl yürütme faaliyetinin deneme alanı; özel şahısların, içinde varoldukları yeni "özel"lik alanının sahici deneyimleri hakkında kendilerini aydınlatma sürecidir". Edebi kamu kapitalizm öncesi dönemde de vardır. Ancak, birçok şey gibi o da saraya ve soylulara aittir. Burjuva sınıfının gelişimiyle halk da özel bireyler olarak edebi kamuya dahil olur. Ekonomik yaşamın merkezi olan kentler sarayın kültürel-siyasal karşıtı olarak edebi kamunun kurumlarını da bağrında taşır (HABERMAS, 2000: 96,7). Bütün bu gelişme sürecinin sonunda kamusal alan, bireylerin ortak sorunlarla ilgili akıl yürüttukleri, ussal bir tartışma içine girdikleri ve bu tartışma sonunda ortak bir kanaat oluşturdukları süreç, araç ve mckanların belirlediği yaşam alanı olmuştur.

Feodal dönemden kapitalist döneme geçişle birlikte kamusal alan yapısal bir dönüşüme uğramıştır. Kamusal topluluk genişlemiş, kamusal alana yeni konular ve yeni aktörler dahil olmuştur. Kamusal topluluğun genişlemesiyle doğrudan tartışmaların yerini medya aracılığıyla yapılan dolaylı müzakereler almıştır. Siyasal kamuya ilişkin anayasal düzenlemeye göre iktidar halktan kaynaklanır. Siyasal kamusal müzakercnin kurumsal güvenceleri hukuk devletiyle oluşturulmuştur. Burjuva hukuk devletinde kamu erki, tarafsızlaştırılmış ve egemenlikten arındırılmış bir özel alanın ihtiyaçlarına tabi duruma gelmiştir (HABERMAS, 2000: 173). Oluşan bu burjuva kamusallığı da toplumsal yaşamın gelişmesiyle kamusal alanın özel alanla kaynaşması ölçüsünde geçerliliğini kaybetmiştir (HABERMAS, 2000: 302). Artık geçerli olan sivil toplumun yarattığı farklılaşmış bir kamudur ve bu kamu sadece politik alanla sınırlı olmayıp toplumsal, kültürel ve kişilik oluşumuna ilişkin alanları da kapsar. Bu açıdan Habermasian modele göre salt elit bir kamusal topluluğun politik büyüklüğ̈̈ ile sınırlı olarak yapılan kamusal alan kavramsallaştırmaları eksiktir (MEADOWCROFT, 2002: 184).

Habermas'a göre, (1999: 47) kamusal alanın, iletişim süreçlerinin "daha yüksck düzeydeki özneler arasıllğı"'nı sağlaması gcrekir. Çünkü, Habcrmasian kamu alanı, halkın ussal, eleştirel müzakereyi amaçladığı bir kamudur (ALDRIDGE, 1999: 85). Böyle bir kamu, farklı yaşam biçimlerinin açık ifadelerini buldukları, tartışmazlık rulıyyla yoğrulmuş bir kamudur. Kamusal müzakere surecindeki tartışmalar sayesinde katılımcılar "kendilerini oluşturan kimliklerin bağlantısal ve olumsal karakterleriyle hesaplaşmaları için firsatları genişletir ve bu da onları yönlendiren ve birbirine göre tanımlayan inançların 
tartışmaya açık karakterini karş̧lıklı kabul eden taraflar arasında saygılı bir çatışma için önkoşulları yaratır" (CONNOLLY, 1995: 226).

Habermas'ın iletişimscl cylcm kuramıyla bağlantılı olarak ortaya koyduğu söylemsel kamu modelinde (JAKSON, 1999) kamusal eylem sürecine, ilgili herkesin, sınırlandırılmaksızın ve kendi olarak katılması esastır. Habermasian kamu alanı, herhangi bir toplumsal kural veya kolektif siyasal kararlara ulaşmada bu kural ve kararlardan etkilenecek olanlara söz hakkı tanıyacak olan yöntemlerin demokratik biçimde oluşturulması gercğini vurgular (SARIBAY, 2000: 6). Bu nedenledir ki, Habermas (1998: 152) kamusal alan açısından kişisel özerkliği en önemli unsur olarak kabul eder.

Habermas, kamusal alanla ilgili görüşlerini kendisine ait olan iletişimsel eylem kuramına bağlı olarak geliştirir. Buna göre kamusal müzakere süreci şu özelliklere sahiptir: Öncelikle, konuşmacılar birbirlcrini söyleme katılma yönünden özgür ve eşit, diyalog sürecindeki rolleri açısından yer değiştirebilir görmeyi karşlıklı olarak kabul ederıcr. İkinci olarak, taraflar ussal uzlaşmaya ulaşmayı amaçlamaktadırlar. Ussal uzlaşma evrenselliğe açık ve tarafšzıdır. Kamusal söylem süreci başkalarının refahına ilgi gösterme ncdeniyle dayanışmacı bir özelliğe de sahiptir (GOULD, 1999: 245).

Habermasian kamu alanı modelinde sonuçlarından doğrudan veya dolaylı olarak etkilenebilecek olan herkesin kamusal söyleme katılması esas olduğu belirtilmesine karşın, kamu alanının öznelerinin kimler olduğu ve diyaloğa girmenin amacının ne olacağı belli değildir. Habermas, ozne endeksli açılamaların konunun yönünü cumhuriyetçi ya da postmodern modellere kaydıracağını, bunun da ya benliğe aşırı etik bir nitelik yüklenmesine ya da öznenin ölümüne neden olacağını belirtmektedir (KEYMAN, 1998: 63). Bu bağlamda Habermas, çözümün modern benlikte olduğunu belirtmektedir. Ancak, modern benliği csas alan demokrasi kuramları genel olarak modern benliğe dayalı homojenleştirici yurttaşlık düzenlemesi nedeniyle geç modern dönemlerin kimlik ve farklılık taleplerine yanıt verememektedir. Bu nedenle öyle bir kamu alanı oluşturulmalıdır ki, ne özneye gereğinden fazla ağırlık vermesi nedeniyle özncyi öldürsün, ne de farklılık taleplerini reddederek tek düzeliğe yol açsin.

\section{YeNi bir KAMU ALANi MOdelinin gereKLiliăi}

Arendt 'in Antik Yunan Polisi'ndeki kamuyu idcalleştirdiği kamusal alan anlayışının günümüz anlamında özgürlük, eşitlik ve çoğulculuk ilkelcri açısından yeni bir kavramsallaştırmaya ihtiyacı vardır. Daha önce de belirtildiği gibi Arendt, Antik Yunan Polisinnin temel özelliklerini oluşturan kimi kavram ve uygulamalara çăgdaş yorumlar kazandırmak için çaba göstermiş, ama 
kamusallığ salt politik bir dünyada mümkün olabilen bir faaliyct olarak nitelemiştir. Oysa, modernleşmeyle birlikte "kamusal başlığı altına alınamayacak, yeniden siyasallaştırılmış bir toplumsal alan" gündeme gelmiştir.

Liberal kamu alanı kamusal topluluk açısından klasiklerdeki sınırlılığından kurtulmuş, ama kamusal gündemin belirlenmesindeki sınırlılığını çağdaş düşünürlerde de devam ettirmiştir. Locke'da sadece hür erkeklere özgü olan kamusal topluluk Mill'de sinırlarını biraz daha genişletmiştir. Kamusal gündeme ilişkin sınırlamalar ise çağdaş liberal düşünürlerde de varlığını sürdürmüştür. Örneğin, yararın veya iyinin ne olduğuna ilişkin yurttaşlar arasındaki farklı ve çelişik kavrayışlar özel alana ilişkin sorunlar olarak görülmektedir.

Habermasian modelde herkesin konuşma özgürlüğü vardır ve her tür çıkar dile getirilebilir. Ancak, herkesin kamusal alana katılması ve kamusal gündeme her tür çıkarın dahil edilebilmesinin arkasındaki neden anlaşmaya ulaşmaktır. Habermasian modelde farklı özneler ve farklı çıkarlardan yola çıkılmakta, ama farklılıkları aşılması gereken unsurlar olarak gören, çeşitliliği artırmak yerine anlaşmayı birincil hedef kabul eden bir sonuca ulaşılmaktadır Yani, bu modelde "çeşitlilik çok sesli bir söylem için ilk koşul"dur; "ama söylemin normatif ilkesi tek sesliliktir" (GOULD, 1999: 246).

Bütün bu nedenlerle yeni bir kamusal alan modeli, hem de Granham'nn belirttiği gibi mevcut toplumsal düzenlemeleri cleştirebilmemize olanak sağlayacak ideal tip bir kamusal alan modeli vazgeçilmez bir zorunluluk durumundadır (aktaran ALDRIDGE, 1999: 85)

Burada, gerckli olan kamusal alan modelinin kapsamh bir açılamasından çok, böyle bir modelin kamusal alana katılım, gündemi belirleme ve nihai çoğulculuk açısından hangi özelliklere sahip olması gerektiği tartışılmıştır.

\subsection{Kamusal Alana Katılım}

Çoğulcu bir demokrasi açısından gerekli yeni bir kamu alanı modeli, katılım yönünden, kamusal kararlardan doğrudan veya dolaylı olarak etkilenebilecek herkese açık olmalıdır. Bunun için irade özgürlüğüne sahip her bireyin kendisini kamusal alanda gösterme hakkı bulunmal, irade özgürlüğü bulunan lierkes özgür kabul edilmelidir. Antik Yunan kamu modelindeki gibi kamusal alana katılma hakkının ekonomik nitelikli evcil işlerden bağımsız erkeklere tanınması, katılım açısından sınırlı bir kamu modelini oluşturacağı gibi, kimi toplumsal kesimlerin özgürlükleri kötüye kullanacakları gerekçesiyle kamusal topluluğun dışında tutulmaları demokrasinin çoğulcu nitcliğini yaralar. Çokkültürcü bakış açısıyla konuya yaklaşıldığında her bir birey tüm 
farklılıkları ile birlikte kamusal alanda yer alabilmelidir. Liberal bakışta ise siyasal olmayan farklılıklar özel alana aittir.

Tüm bireyler insan olmak bakımından cşit olmalarına karşın, belli bir noktadan sonra cinsel, dilsel, dinsel v.b. yönlerden farklılık gösterirler. Bireylerin bu çeşit farklılıkları, çoğunlukla, genelleştirilebilir çıkardan farklı ve bağımsızdır. Bu nedenle, bu farklılıklar kamusal anlaşmalar için belli koşullara dayandırılmamalıdır.

Kamusal yaşamda farklılıklara olumlu yaklaşılmaması onların kamusal akıl açısından aşkın bir bölünmenin nedeni olarak görülmesinden kaynaklanır. Young'in da (1999: 184-187) belirttiği şekilde, farklılıklar kamusal akla düşünsel bir kaynak oluşturduğu gibi, farklı tercihler arası dönuş̧ümlere yol açarak toplumsal kaynaşmaya da yardımcı olabilir. Farklı bakış açıları arasındaki dönüşüm şu üç türde oluşabilir:

a) Belli bir konuda belli bir bakış açısına sahip bir birey, öteki bireylerin bakış açılarındaki farklılığı görünce, kendi bakış açısının çoğul gerçeğin tekil bir yanını oluşturduğunu fark eder.

b) Ötcki bakış açıları karşısında birey, kendi bakış açısını daha cazip duruma getirmek istek ve mücadelesi içine girecektir. Bu durum kamusal müzakerevi özneler açısından daha çekici, sonunlara çözüm bulma açısından daha verimli kılacaktır.

c) Farklı bakış açıları, farklı bilgi kaynakları ile beslendiğinden kamusal müzakereye katılım, her katılımeı özne için artan bilgi demek olacaktır. Böylece, kamusal alana katılım yönünden sınırların geniş tutulması daha çok bilgi, daha çok düşünce ve daha çok çözüm anlamına gelecektir.

Demokrasi, yurttaşları için olası en çok özgürlük ve eşitliği birleştiren bir yönetim biçimi (LIPSON, 1993: 17) olduğundan ona kaynaklık edecek kamusal alanın da toplumsal ilişkiler ve bu ilişkilere karşılık gelen özne konumlarının çoğul olmasını gerektirir (MOUFFE, 1988: 101).

Bircyin kendini öznc olarak konumlandırabilmesi, Touraine'e göre (1997: 24) kesinlç̧miş özgürlüğünün ve özgün biçimi yok edilmeksizin yorumlanan deneyiminin birleşmesiyle eyleyen hale gclebilmesini ifade eder. Bireylerin kamusal alana bu şekilde katılımı sonuç olarak eşitliği getirir. Zaten, katılım ekseninde özgürlük ve eşitliği esas alan bir kamu, "aynı bütünün içinde birbirinden farklı, hatta birbirine karşıt olan, kısacası aynı zamanda hem birbirine benzeyen hem de birbirinden ayrilan birey ve öbckleri bir arada" yaşatabilen bir kamudur (TOURAINE, 1997: 277). 


\subsection{Kamusal Gündemin Saptanması}

Arendt'in kamu alanı görüşünde rckabetçi kamu alanı söz konusu olduğunda, gündem, herhangi bir yurttaşın diğer yurttaşlardan farklı olarak sahip olduğu ve kamusal alanda göstermek istediği bir üstünlükten oluşmaktaydı. Bu durumda gündem bizzat katılımcı tarafindan oluşturulur. Birleşimsel modelde ise gündem tüm yurttaşların üzerinde uzlaşarak uyum içinde birlikte olmalarını sağlayan bir sorundur. Birleşimsel model söz konusu olduğunda gündemin nasıl ve kimlcr tarafından belirleneceği Arendt tarafindan özel olarak açıklanmıs değildir. Bu durumda katılımcıların belirlenmiş olan gündem üzerinde mi müzakere edcbilcceği, yoksa gündeme yeni konular mı taşıyacakları, hatta böyle bir haklarının olup olmadığı belirsizdir. Ayrıca, modernleşmc sonucu oluşan yeniden siyasallaştırılmış toplumsal alana ilişkin konuların kamusal alanın gündemine taşımı taşınamayacağı da Arendţ̧i kamusal alan kavramsallaştırmasında açıklanmaya muhtaçtır.

Liberal kamu anlayışında hem klasik liberal görüşte hem de çağdaş liberallerde kamusal gündem sadece siyasal görüş farklılıklarına açıktır. Örnç̆in, Lockc'a göre sözleşme sırasında kültürel farklılıklar ile toplumsal kesimler arası statüden kaynaklanan farklılıklar siyasal olmadıkları için görmezden gelinmektedir. Rawls ise kamusal gündemi anayasal temeller ve temel adalet sorunlarıyla sinırlandırdığı gibi, kamusal müzakereyi toplumsal alanda niteliksel kamusallık açısından da sinırlandırmaktadır.

Bu nedenle, kamusal alana katılımın özgürlük ve eşitlik ilkelerine uygun olarak kamusal kararların sonuçlarından etkilenebilecek olanlara açılması, çoğulcu yeni bir kamu modeli için gerekli, ama yeterli değildir. Birey ya da grup kimliğinin siyasal, sosyal ve kültürel boyutları birbirinden bağımsız olmadığı için konuyla ilgili ikinci bir adımın atılması gerekir ki, bu da gündemin belirlenmesinde herkesin eşit ve özgür olmasıdır. Bu amaçla şu ǚç koşulun gerçekleştirilmesi gerekir: Öncelikle, bütün katılımcılar toplumsal konum ve ekonomik güçlerinden bağımsız olarak eşit söz hakkına sahip olmalıdırlar. Bu koşulun tam anlamıyla sağlanabilmesi için sağlık nedeniyle müzakereye katılmada kimi zorlukları bulunan yurttaşların katılımcı olabilmcleri sağlık engellerinden bağımsız olarak sağlanmalıdır. İkinci olarak, katılımcıların müzakere özgürlügü herhangi bir norm tarafindan önceden sınırlandırılmamalıdır. Son olarak, katılımcılar üzerinde müzakere özgürlüğünü kısıtlayıcı bir siyasal baskı bulunmamalıdır.

Bu koşullar altında katılımcı yurttaşlar belirlenmiş bir gündemi herhangi bir ekonomik, siyasal ve norma dayalı kısıtlama olmaksızın müzakere edebilecekleri gibi, kendileri de gündeme yeni konular getirebilirler. Çeşitli sınırlandırmalar nedeniylc gündeme yeni konular getirememe ya da önceden 
saptanmış belirli konuları müzakere sürecinin dışında bırakma, katılımcıların düşünme ve ifade özgürlüğünün sınırlandırılması anlamına gelir. Hatta, böylc bir durumda kimi konu ve nesneler sadece müzakere sürccinin dişında değil, soyut düşünme etkinliğinin bile dışında tutulmuş olur. Böylesine sınırlı bir gündeme dayalı kamu alanının çoğulcu bir demokrasiyc altyapı sağlayamayacağı açıktır.

\subsection{Nihai Goğulculuk}

Habcrmas'ın söylemsel kamu modeli yurttaşları özgür ve eşit konuşmacılar olarak kabul etmekte, ama kamusal müzakereyi son tahlilde tekil bir uzlaşma amacına odaklandırmaktadır. Buna bağlı olarak Habermas, alınan kararların meşru olduğunu, çünkü herkesin söylcme dayalı irade oluşumuna özgür ve eşit olarak katıldığını ve ilgili bütün tarafların baskı altında kalmadan anlaşmaya vardıklarını belirtmektedir (aktaran GOULD, 1999: 249). Ancak, bu durum meşruiyeti salt bir yöntemsel konuma indirgemekte ve kamusal müzakere sonucu alınacak kararların özsel meşnuiyetini göz ardı ctmektedir.

Liberal çoğulculuk açısından nihai çoğulculuk, farklı çıarlar ve farklı iyi anlayışları nedeniyle toplumsal alanda olabilir. Ancak, siyasal alanda nihai çoğulculuk çok sınırlıdır. Örneğin, Rawls'un görüşlerinden harcket edildiğinde siyasal adaletin ilkeleri konusunda bir nihai çoğulculuktan söz edilemez. Bu konuda olsa olsa kamusal akla ulaşmanın yollarının farklılığı açısından bir nihai çoğulculuk söz konusu olabilir. Ama, çokkültürcülük açısından konuya yaklaşıldığında kimi durumlarda siyasal alanda nihai çoğulculuğa yer verilmediğinde öznelerin özgürlüğü ve dolayısıyla eşitlikleri sınırlandırılmış olur. Yani, kendi siyasal iyilcri, üzerinde uzlaşmaya varılan tekil siyasal iyi ile örtüşen kesimler lehine ve doğal olarak diğer kesimlerin aleyhine özgürlüik ve eşitlik açısından elverişsiz bir durum oluşturulmus olur. Zira, değer ve çıkar çatışmalarının yüksek düzeyde seyrettiği bir toplumda siyasal alana yansıtılamayıp toplumsal alanla sınırlı kalan bir çoğulculuk ortak değcrleri ve ortak çıarları yansıtmak noktasında yetersiz kalacaktır. Tüm bu yetersizlikleri kamusal müzakere sürecindcki yöntemsel meşruiyet kapatabilecek değildir. Nihayet, eşitlik, özgürlük ve çeşitlilik çerçevesinde başlayan kamusal müzakere tekil, homojen ve hegemonyacı bir biçimde sonuçlanabilcccktir. Böyle bir durumda azınlık, çoğunluğun olası bir baskısından nasıl korunacaktır? Üzerinde uzlaşılan karara itiraz etmeden, ama kondi farklı değerlerine dayal eylemlerini çoğunlukla çatışmaya girmeksizin uygulamak isteyen azınlığın bu kararına saygı duyulup izin verilmesi nasıl sağlanacaktır? Bir ülkede önemli olan, yönetilenleri, sadece yöneticilerin baskısından korumak değildir. 
Toplumun bir kesimini diğer kesim veya kesimlerin eşitliksiz ve adil olmayan baskılarından korumak da ayn derecede önemlidir.

Benhabib (1999: 117) böyle bir korumanın "cvrensel ahlaksal sayg"" ve "eşitlikçi karşılıklılık" ilkclcriyle sağlanabileccğini belirtmektedir. Bu ilkclerle hareket cdilmesi durumunda kamusal müzakereye katılanlar, birbirlerini karşılıklı olarak özgür ve eşit kabul eder ve kamusal müzakerenin gündemine yeni konular getirmek bakımından aynı simetrik haklara sahip kişiler olarak görürler. Dolayısıyla, bireyler birbirlerini cvrensel ahlaksal saygı ve eşitlikçi karşılıklılığa hak kazanmış varlıklar olarak görünce çoğunluğun azınlık üzerindcki olası bir baskısı da daha baştan önlenmiş olacaktır.

Kanımca Benhabib'in öncrisinin çoğulcu bir toplumun gereksinmelerine yanıt vercbileceği kuşkuludur. Yapılan öneri ancak etik düzeyi yüksck toplumlarda geçerli olabilir. Farklılaşmanın olabildiğince arttı̆̆ günümüzde toplumların yüksek bir etik düzeyinden harcketle etkileşimde bulundukları ön kabulünden harcket etmck ise fazla gerçekçi olmayacaktır. Bu nedenle günümüz ileri toplumları için nihai çoğulculuk açısından yeni bir kamusal alan modeline ihtiyaç vardır.

İhtiyaç duyulan yeni kamusal alan modeli nihai çoğulculuk açısından çeşitliliğc açık olmalı, belli bir konuda tekil ortak yarar yerine çoğul ortak yararlar gerçeğinden hareket etmeli ve bu çoğulluk gerçeğini nihai karara yansıtmalıdır. Günümüz ilcri toplumlarında çok sayıda farklı yaşam biçimi bulunmaktadır. Kamusal müzakerenin amacı, bu farklı yaşam biçimlerine sahip kesimlerin bir arada ve barış içinde yaşamalarmın sağlanmasıdır. Bu amaçla öyle bir sistem oluşturulmalıdır ki, sistem, yurttaşlar arasında, onları herhangi bir kimlik kabulüne zorlamadan bir eşitlik sağlamalı, "ama üstünlük veya aşağılık biçiminde bozulmamış" bir farklılı isteğini de olumlu karşılamalıdır (TODOROV, 1985: 249).

Bunun için çeşitliliğin normatif yönü büyük önem taşır. Çcşitliliği normatif yönüyle ele almak bir toplumsal kültürde yer alan farklı yaşam biçimlerinin varlığını kabul cdip, kültürel çeşitliliği başlıca bir değer olarak benimsemek demektir. Böyle bir kabulün doğal sonucu her farklı yaşam biçimine ait çç̧itli konuların kamusal gündemde yer alabilmesi ve nihai kararda da kendi ifadesini bulabilmesidir. Farklı yaşam biçimlerinin varlığı farklı iyi anlayışların da göstergesidir. Nihai kararın tekil bir uzlaşıdan ibaret olması durumunda bu tckil karar, yansıttığı iỵi anlayışı açısından azınlıkta kalanların ị̀i anlayışlarıyla uyuşmayan bir karar olacaktır. Bu durum azınlığın, çoğunluğun iyi anlayışının baskısında kalmasımı gerektirccek ve kamusal müzakereye özgürce katılan yurttaşların müzakerc sonucunda özgür olamaması gibi çelişik bir sonuca neden olacaktır. Böylc bir sonucu ahlaki çoğulculukla bağdaştırmak olası değildir. Çünkü, nihai kararın tekilliği, azınlıkta kalanların 
çoğunluğun iyisi için feda edilcbileccği anlamına gelir. Oysa, ahlaki çoğulculuk farklı iyi anlayışlarını üstün bir iyiye göre sıralamayı reddeder (BERLIN, 1998: 99-101).

Çcşitliliğin normatif kabulü yaşamın farklı yönlerinin görülebilmesini sağlar. Bu sayede herhangi bir toplumsal kesim, kendi yaşam biçiminden farklı, daha başka geçerli yaşam biçimlerinin olduğunu gönür. Yaşamın böylesine bütüncül algılanışı kamusal müzakerenin sonucuna da bütüncül olarak yansımalıdır ki, özgür ve eşit olarak başlanılan bir kamusal müzakerenin sonucunda katılımcıların özgürlüğü ve eşitliği korunabilmiş olsun.

\section{SONUC}

Kamusal alanın üç farklı kavramsallaştırması olan Arendtian, Habermasian ve libcral modellerin çoğulculuk açısından değerlendirildiği bu çalışmada mevcut modellerin olumlu yanları ile cksikliklcri ortaya konularak, gerekli, yeni bir kamusal alan modelinin taşıması gercken özellikler belirlenmeye çalışılmıştır. Buna göre, Arendtian model yeni bir kavramsallaştırmaya gereksinme göstermektedir. Çünkü, Arendt'e göre insan eylemde bulundukça özgürdür. Politik alan bir cylem alanı olduğundan insanlar açısından özgürlük, farklılık ve çoğulluk bu alanda ortaya çıkar. Ancak, modernleşmeyle birlikte insanların eylemde bulunabilecekleri, dolayısıyla, özgürlük, farklılık ve çoğulluklarını ortaya koyabilecekleri politik alan dışında yeni alanlar belirmiştir.

Liberal model kamusal gündemi sınırlamaktadır. Bu sınırlama bazen bircy veya grup kimliğinc ilişkin kimi toplumsal ve kültürel nitelikli sorunların kamusal gündeme getirilemeyeceği anlamını taşı $\mathrm{ki}$, bu durum çoğulculuğa terstir. Kaldı ki, kendi farklılıklarını kamusal olarak dillendiremeyen kimselerin özgür ve eşit oldukları da söylenemez.

Habermasian modelde çoğulculuk, nihai karara kadar olan aşama için söz konusudur. Nihai karara yansımayan bir çoğulculuk ise, siyasal iktidarın özsel meşruiyetini sağlayamaz. Zira, toplumsal farklı kesimlerin sadece kamusal alana giriş ve kamusal gündemin bclirlenmesi açısından özgür ve eşit olarak kabul edilmeleri çoğulculuk açısından yeterli değildir. Siyasal çoğulculuğun gerçckten varolabilmesi için farklı kesimlerin bu farklılıkları nihai kararda yer alabilmelidir. Tersi bir durum, farklılıkların çoğunluğun insafına bırakılması ile eş anlamlıdır.

Gelinen bu noktada mevcut kamusal alan modelleri gercksinmelere yanıt vermekten uzaktır. Çünkü, temel hak ve özgürlükler ile demokraside yeni gelişmeler olmuştur. Farklılığa ilişkin talepler, neredeyse dördüncü bir kuşak hakkın konusu haline gelmiş; demokraside ise halktan çok özneye vurgu 
yapılmaya başlanılmıştır. Bütün bu nedenlerle nihai karar açısından çoğulculuğa yer veren yeni bir kamusal alan modeline ihtiyaç vardır.

\section{Kaynakça}

ABERCROMBIE, Nicholas/HILL, Stephen /TURNER, Bryan S. (1994), The Penguin Dictionary of Sociology (London: Penguin).

ALDRIDGE, Merly (1999), "Probation Officer Training, Promotional Culture and the Public Sphere," Public Administration, 77/1: 73-91.

ARENDT, Hannah (1994), Insonlik Durumu (istanbul: Iletișim Yayınlarl).

BENHABIB, Seyla (1996), "Kamu Alanı Modelleri," Cogito, 8: 238-258.

BENHABIB, Seyla (1999), "Müzakereci Bir Demokratik Meşruiyet Modeline Doğru," BENHABIB, Seyla (Der.), Demokrasi ve Farklilik (İstanbul: Numune Matbaası): 101-139.

BERKTAY, Fatmagül (2002), "Heidegger ve Arendt'te Özgürlük: Bir Kesișme Noktasi," KEYMAN, E. Fuat (Der.), Liberalizm, Devlet, Hegemonya (istanbul: Everest Yayınları):88-104.

BERLIN, Isaiah (1969), Four Essays on Liberty (Oxford: Oxford University Press).

BERLIN, Isaiah (1998), "ideal Arayıșı Üstüne," Liberal Düşünce, 3/12: 94-104.

CONNOLLY, William E. (1995), Kimlik ve Farklılik (İstanbul: Ayrıntı Yayınları) (Çev.: F. Lekesizalın).

CROWDER, George (2002), "Two Value-pluralist Arguments for Liberalism," Australian Journal of Political Science 37/3: 457-473.

GOULD, Carol C. (1999), "Çeşitlilik ve Demokrasi: Farklılıkların Temsili," BENHAB!B, Seyla (Der.), Demokrasi ve Farklilik, (İstanbul: Numune Matbaası): 244-267.

GÜRiz, Adnan (1963), Faydacı Teoriye Göre Ahlak ve Hukuk (Ankara: A.Ü. Hukuk Fakültesi Yayınlari).

HABERMAS, Jürgen (1998), "Siyasal Kuramin Sorunları Üzerine Bir Söyleși," Cogito, 15: 141-158.

HABERMAS, Jürgen (1999), "Demokrasinin Üç Normatif Modeli," BENHABIB, Seyla (Der.), Demokrasi ve Farklilik (Istanbul: Numune Matbaası): 37-50.

HABERMAS, Jürgen (2000), Kamusalliğın Yapısal Dönüșümü (Istanbul: Iletişim Yayınları) (Çev.: T. Bora, M. Sancar).

HAYEK, Friedrich A. Von (1994), Kanun, Yasam Faaliyeti ve Özgürlük -1 (Ankara: Türkiye is Bankası Kültür Yayınları) (Çev.: A. Yayla).

HAYEK, Friedrich A. Von (1995a), Kanun, Yasama Fooliyeti ve Özgürlük -2 (Ankara: Türkiye is Bankası Kültür Yayınları) (Çev.: M. Erdoğan).

HAYEK, Friedrich A. Von (1995b), Kölelik Yolu (Ankara: LDT Yayınları) (Çev.: T. Feyzioğlu, Y. Arsan).

HAYEK, Friedrich A. Von (1997a), Hukuk, Yasama ve Özgürlük (Ankara: Türkiye İş Bankası Kültür Yayınları) (Çev.: M. Óz).

HAYEK, Friedrich A. Von (1997b), "Kuruculuğun Hatalar," Liberal Düșünce (Çev.: S. Coșar), 2/7: 110-124.

JACKSON, Neil (1999), "The Council Tenants' Forum: A Liminal Public Space Between Lifeworld and System?," Urban Studies, 36/1: 43-59.

KESKIN, Ferda (1998), "Kamusal Alan ve Yalın Yașam," Doğu Batı, 2/5: 95-99.

KEYMAN, Fuat (1998), "Kamusal Alan ve Cumhuriyetçi Liberalizm: Türkiye'de Demokrasi Sorunu", Doğu Batı, 2/5: $57-72$.

KÖKER, Levent (1996), "Chartes Taylor: Kimlik/Farklıtık Sorununa Sahici Demokratik Çözüm Arayışı," GUTMANN, Amy (Der.), Cokkültürcülük (Istanbul: Yapı Kredi Yayınları): 11. 14.

KUKATHAS, Chandran (1990), Hayek and Modern Liberalism (Oxford: Clarendon). 
LIPSON, Leslie (1993), "Demokrasinin Felsefesi," YAYLA, Atilla (Der.), Sosyal ve Siyasal Teori (Ankara: Siyasal Kitabevi): 16-22.

LOCKE, John (1986), "Uygar Yönetim Üstüne Ikinci Incelemeden Seçme Parçalar," TUNÇAY, Mete (Der.), Batıda Siyasal Düșünceler Tarihi - 2 (Ankara: Teori Yaynlanı): 225-258.

MEADOWCROFT, John (2002), "The European Democratic Deficit, the Market and the Public Space: A Classical Liberal Critique," The European Journal of Social Sciences, 15/3: $181-192$.

MLL, John Stuart (1986), "Temsili Hükümet Üstüne Düşünceler'den Seçme Parçalar," TUNÇAY, Mete (Der.), Batıda Siyasal Düșünceler Tarihi - 3 (Ankara: Teori Yaymları): 63-92.

MILL, John Stuart (1988), Hürriyet (İstanbul: MEGSB Yayınlari) (Çev.: M. O. Dostel).

MOUFFE, Chantal (1988), "Hegemony and New Political Subjects: Toward a New Concept of Democracy," NELSON, Cary/GROSSBERG, Lawrence (Der.), Marxism and the Interpretation of Culture (Urbana: University of Illinois Press): 89-104.

RAPPA, Antonio L. (2002), "Modernity and the Politics of Public Space: An Introduction," The European Journal of Social Sciences, 15/1: 5-10.

RAWLS, John (1993), Political Liberalism (New York: Columbia University Press).

SABINE, George (1969), Batıda Siyasal Düșünceler Tarihi - 2 (Ankara: Türk Siyasi Ilimler Derneği Yayıni) (Çev.: A. Öktem).

SARIBAY, Ali Yașar (2000), Kamusal Alan, Diyalojik Demokrasi ve Sivil Itiraz (istanbul: Alfa Yayınlari).

SARTORI, Giovanni (1996), Demokrasi Teorisine Geri Dönüş (Ankara: Yetkin Yayınları) (Çev.: T. Karamustafaoğlu - M. Turhan).

STEINBERGER, Peter J. (1999), "Public and Private," Political Studies, 47/2: 292-315.

TAYLOR, Charles (1996), "Tanınma Politikası," GUTMANN, Amy (Der.), Çokkültürcülük (İstanbul: Yapı Kredi Yayınları): 42-84.

THIEMANN, Ronald (1996), Religion in Public Life: A Dilemma for Democracy (Washington D.C.: Georgetown University Press).

TODOROV, Tzvetan (1985), The Conguest of America: The Question of the Other (New York: Harper and Row).

TOURAINE, Alain (1997), Demokrasi Nedir? (Istanbul: Yapı Kredi Yayınları) (Çev.: O. Kunal).

WOLIN, Sheldon S. (1999), "Elle Tutulmaz Demokrasi," BENHABIB, Seyla (Der.), Demokrasi ve Farkllik (istanbul: Numune Matbaası): 51.71 .

YOUNG, Iris M. (1999), "iletișim ve Öteki: Müzakereci Demokrasinin Ötesinde", BENHABIB, Seyla (Der.), Demokrasi ve Farklılik (istanbul: Numune Matbaası): 174-196.

YÜRÜŞEN, Melih (2001), "Çoğulculuk: Sorunlar, Sınırlar ve Imkanlar," Liberal Düșünce, 6/22: 116.128. 